ready for the period of intense solar activity in 1968 , an all-Chinese digital computer has been developed and a new fossil skull of Pekin man found. It may be that the Chinese have also perfected a gas centrifuge technique for the production of uranium 235. Obviously, in spite of being larded with and attributed to the thoughts of Mao Tse Tung, both applied and basic science have continued through the upheaval. And Dr Oldham made the interesting point that there is nothing wrong with Mao Tse Tung's scientific maxims. When they are stripped of their jargon they boil down to such truisms as "Do not be overawed by what authorities in science say, be willing to challenge their beliefs". No one would quarrel with this. Naturally enough the maxims are aimed at the mass of a poorly educated population and they may not be a great benefit to well educated scientists, but they would not do much harm either.

But although science has not been stopped by the cultural revolution there has been a distinct change of emphasis. Any country in China's position trying quickly to apply science and technology to its economy faces two problems. What technologies are most appropriate for its stage of development and where should the technologies come from ? The country can either try to develop the most advanced technology, even though it is expensive and uses little manpower, or it can use less sophisticated technology and more labour. Equally it can import a technology or try to do its own research and development. As events in most developing countries have shown, striking the right balance between these alternatives is extremely difficult. Before the cultural revolution, China seemed prepared to import science and technology. As Dr Oldham interprets it, the main conflict of the cultural revolution, as far as science and technology is concerned, has been about the extent to which the Chinese should become self-reliant. If economic development were the sole criterion, the policies ascribed to Liu and his followers, who were prepared to rely heavily on imported science and technology, were probably right. But if total development-economic, social and political-is the aim, the self-reliance policy of the revolution makes sense. The new policy is more introspective and isolationist, but it is likely to result in a greater concentration of scientific and technological resources on problems primarily relevant to China's development. That is a loss to world science and to individual Chinese scientists who have lost some freedom of research and will no longer be competing on a world stage. For this reason it is crucial that formal contacts, such as betwcen the Royal Society and the Chinese Academy of Sciences, be maintained and if possible expanded. But Dr Oldham is probably right in saying that, for China as a whole, what has happened may be a gain.

\section{Future Foretold}

from our Special Correspondent, Gif-sur-Yvette

Turoughoot this week an unusual meeting has been taking place near Paris. At an elegant chateau which forms part of the French National Centre for Scientific Research (CNRS) at Gif-sur-Yvette, experts from all over France - and some from other parts of the worldhave been discussing what the world will be like in the year 2020. To keep the discussion within sensible limits, it has been set in a geographical context so that each day has been spent discussing the way in which different technological developments will affect the way land is used. It is clear that this meeting, known as the Symposium on Urban Planning and Advanced Techniques, is intended to be the first of a series which could, no doubt, last long enough for the results of this meeting to be compared with the reality of 2020 . But the discussions in the past week have been more limited; they have been restricted to developed countries and have covered five broad topies-power and natural resources, data processing and transmission, communications and telecommunications, agriculture and rural space, and urbanization.

The inspiration for the mecting seems to have derived from Mr. Jerome Monod, a French government official responsible for regional development and planning. But the origins are obscure, and it is probable that Mr Jacques Bloch-Morhange, a man with a catholic range of interests including, it is said, the breeding of racehorses, had something to do with it. Mr BlochMorhange is acting as secretary-general of the conference. The organizing committee of five, drawn from universities and government service, did most of the preparatory work which included commissioning studies by experts in the subjects concerned. The immediate practical benefit seems to be to help the French Government to formulate the Sixth Plan, but the organizers also see it as a way of helping administrators to avoid making decisions which are immediately overtaken by events.

The conference has been conducted at a philosophical level divorced in the main from immediate considerations such as those of finance. It was possible, for example, for the greater part of a discussion on the benefits of data processing to be completed before anybody asked if the financial investment in France would be great enough to sustain the hopes which had been expressed. But the discussion had not been futuristic-if anything the estimates of power and natural resources had erred on the side of conservatism. To be told that by 2020 half the electricity consumed would be generated by nuclear power, with the other half derived from hydrocarbon sources, astonished nobody. To this extent, the predictions have been unexceptionable, even unadventurous; but that they will help to formulate policies in the next five or ten years is undeniable. Much will depend on those who have to write the final report and draw together the results of what has been rather diffuse discussion. While it has been an interesting exercise, it is not immediately clear how the broad policy implications suggested by the week's discussion can be implemented in the face of the financial restrictions which normally determine events.

\section{Donnish Productivity}

BRITISH universities, enlivened no doubt by the scrutiny to which they are now subjected by the Comptroller and Auditor General, have been discussing the efficiency of their operations. To judge from the discussion 
among university delegates to a conference called jointly by the Committee of Vice-Chancellors and the Associalion of University Teachers on March 21, the cause of university productivity has made some worthwhile advances since the Committee of ViceChancellors first took an official interest in the subject two years ago. It is hard, however, to tell precisely how the universitics reacted to some of the proposals now being made, for the universities seem to be as jealous of the privacy of their discussions as of any other academic freedom.

The conference on March 21 was opened by Mr C. F. Carter, vice-chancellor of the University of Lancaster and the British prophet of university productivity. The essence of his ease was that teachers, and the way in which their work is organized, are more immediate limitations of the output of qualified students from universities than are buildings and other kinds of equipment, so that "increases of productivity are thercfore most likely to be achieved by a better organization of labour or by harder work". Both in teaching and in research, according to Mr Carter, better productivity could be obtained by having fewer small departments, by not using highly trained staff for work that could be done by others, by spending more capital on educational technology, by organizing staff time more efficiently and by working harder. "And why not? American academics do. It would help if more payment was on piece rates." Mr Carter would also like to see a redefinition of the division between teaching and research, and he considers that the more efficiont use of buildings would make it possible for universities to double student numbers "even before using such obvious expedients as lengthening the very short teaching day". In Mr Carter's view, the university year should be organized on a staggered pattern with each student sponding two out of three equal terms at the university each year. He wants to sec more sharing of expensive equipment, a reduction of committee work and "a drastic reduction in the circulation of paper".

How did all this go down? Several speakers at the conference were more concerned than Mr Carter with the philosophical definition of what is meant by university productivity. Something of this sort may cventually come from the work of $\mathrm{Mr} \mathrm{K}$. S. Davies, seconded to the Committee of Vice-Chancellors as a research officer, who is engaged on a long-term study of the factors which affect university productivity. Dr M. Blaug, of the University of London Institute of Education, took a still longer look at the problem of measurcment, and was particularly anxious that the concepts of productivity and efficiency should not be confused. He would like there to be a continuing comparison of scores in student attainment tests at the beginning and at the end of university courses, studies by educational psychologists of the effectiveness of different teaching methods, more information about the socio-economic character of students and about their economic prospects, and some attempt to construct objective vardsticks for the evaluation of research.

It seems that only a minority of those present thought that studies of this sort were undesirable. One count showed that only three out of lwenty-four speakers werc against, with the rest in favour. 'This marks a great change of opinion in the past five years. It even seems to have been possible for Mr Carter to get away with the claim that university teachers in the United States work harder than those in Britain. Dr D. G. Christopherson, chairman of the Committec of Vice-Chancellors, said after the meeting that the universities did not feel themselves to be under immediate pressure. Thcy were, he said, looking forward to the next period of fast expansion in the seventies. And the suggestion that the universities fear that if they do not begin to measure their own productivity, somebody less sympathetie will come along and do it for them was indignantly denied. Professor Blaug called it "an uncharitable suggestion".

\section{Rockefeller Without Bronk}

\section{New York, March}

THE resignation of Dr Detlev W. Bronk as president of the Rockefeller University later this year will amount to something like the end of an era in the affairs of the university, until 1964 the Rockefeller Institute. By common consent, Dr Bronk has been almost entirely responsible for the directions which the institute's growth has followed since his accession to the presidency in 1953 (after several years as president at Johns Hopkins). He has been consistently expansionist, with the result that the faculty has grown in size and lustre. He has also consistently fought for a recognition of the educational responsibilities of the people at the Rockefeller Institute, which is how the institute has acquired the distinction of being an inde-


pendent university without undergraduates. Although there are few among the faculty who are unmoved by Dr Bronk's vision of the part his institution might play in the academic life of the United States, there have frequently been occasions when the president and the faculty have moved ahead at different spoeds. The creation, within the past year, of an academic council at the Rockefeller University should help to ensure that the balance of power between the faculty and Dr Bronk's successor is more even.

'There is no doubt that Dr Bronk's carcer is one of almost unparalleled distinction. For several years he has divided his immense energy between government and universities. His spell as president of the United States National Academy of Sciences, between 1950 and 1962, saw a vigorous growth of the academy's influcnce in Washington and elsewhere, largely as a result of the drive which Dr Bronk imparted to the job. In the circumstances, it is not surprising that Dr Bronk should plan not to settle back into retirement when his present appointment ends. He says that he will keep on a laboratory at the Rockefeller University, as is the custom for retired professors at the institution. At least until the election campaign is further advanced, he says that he intends to maintain a "flexible" position, which presumably implies that he will be ready to accept a call to another Washington job. In any 